\title{
Problems in Diagnosis of NonAA Renal Amyloidosis
}

\section{AA Dışı Böbrek Amiloidozlarında Tanısal Sorunlar}

\author{
Sait ŞEN', Banu SARSIK', Özsan NAZAN', Bozkurt DEVRiM², Çağırgan SEÇKiN \\ Department of ${ }^{1}$ Pathology, ${ }^{2}$ Nephrology and ${ }^{3}$ Hematology, Ege University, Faculty of Medicine, IZMIR, TURKEY \\ This study was supported by Ege University (03 TIP 008)
}

\section{ABSTRACT}

Objective: Amyloidosis represents extracellular deposition of congophilic fibrils of similar morphology but different chemical composition. The types frequently involving the kidney are AA (serum amyloid A) and AL (light chain amyloid). Hereditary amyloidoses, which can also affect the kidney, are being described with increasing frequency. Distinguishing the type of amyloid is important because of the different treatments and outcomes. Typing of amyloidosis by immunohistochemistry (IHC) is believed to be unreliable, except for AA amyloid. We reevaluated our cases in this study to draw attention to the nonAA amyloid deposits in renal biopsies with amyloidosis.

Material and Method: Renal biopsies diagnosed as amyloidosis between 1997 and 2008 were stained for amyloid A with IHC. Cases with negative amyloid A staining were included in the study.

Results: We found 190 cases of renal amyloidosis (198 biopsies) during the study period. Thirty cases (33 biopsies) with negative antiAA staining were studied. Among those 30 cases with nonAA amyloidosis, secondary AL amyloidosis was due to multiple myeloma in 8 cases and plasma cell dyscrasia in 2 cases. Hereditary renal amyloidosis was suspected in some cases.

Conclusion: Using amyloid A IHC on a routine basis and the clinical history are essential to diagnose AA amyloidosis. The differential diagnosis of nonAA amyloidosis may be inconclusive on IHC. The diagnostic approach should be multidisciplinary and requires careful clinical and pathological evaluation. The limitation of IHC may necessitate direct typing of the amyloid protein extracted from paraffin-embedded specimens in some cases.

Key Words: Kidney, Amyloidosis, AA amyloidosis, AL amyloidosis, Hereditary amyloidoses

\section{öz}

Amaç: Amiloidoz benzer morfolojiye sahip ancak farkl kimyasal kompozisyonları olan kongofilik fibrillerin hücre dışında birikimini gösterir. Böbreği yaygın olarak tutan tipler AA (serum amiloid A) ve AL'dir (hafif zincir amiloidi). Fakat böbreği de etkileyebilebilen herediter amiloidozlar artan sıklıkta tanımlanmaktadır. Amiloid tipine göre tedavi ve prognozu değişeceği için, tiplendirilmesi önemlidir. AA amiloid dişındaki amiloidlerin immünhistokimyasal (İHK) olarak tiplendirilmesinin güvenilir olmadığına inanılmaktadır. $\mathrm{Bu}$ çalışmada, amiloid birikimi olan böbrek biyopsilerinde nonAA amiloid birikimlerine dikkat çekmek için olgularımızı yeniden değerlendirdik.

Gereç ve Yöntem: 1997-2008 arasında amiloid birikimi olan böbrek biyopsileri İHK olarak amiloid A boyandı. Bu çalışmaya amiloid A boyaması negatif olan olgular alındı.

Bulgular: Çalışma periodunda 190 olguda (198 biyopsi) amiloidoz saptand. AntiAA boyaması negatif olan 30 olgu (33 biyopsi) çalışmaya alındı. NonAA amiloidozlu olan 30 olgudan sekizinde multipl myelom, ikisinde plazma hücre diskrazisine sekonder $\mathrm{AL}$ amiloidoz bulundu. Olguların bazılarında herediter amiloidozlardan kuşkulanıldı.

Sonuç: AA amiloidozu tanımak için rutinde amiloid A için İHK inceleme uygulanması ve klinik hikayenin araştırılması önemlidir. NonAA amiloidozların İHK olarak ayırıcı tanısı kesin olmayabilir. Tanı yaklaşımı multidisipliner olmalıdır, klinik ve patolojik değerlendirme dikkatli yapılmalıdır. Bazı olgularda İHK incelemenin sınırları nedeniyle, parafine gömülü dokulardan çıkarılan amiloid proteinleri ile direkt tiplendirme gerekebilir.

Anahtar Sözcükler: Böbrek, Amiloidoz, AL amiloidoz, AA amiloidoz, Herediter amiloidozlar

\section{INTRODUCTION}

Amyloidosis is a heterogenous group of diseases that appears as extracellular accumulation of various amyloid proteins in many tissues. At least 25 different precursor proteins are now known to cause amyloidosis (1). There may be accumulation at various compartments of the

Received : 06.04.2009

Accepted : 02.06.2009 kidney at various degrees in systemic amyloidoses. Different clinical pictures may be encountered depending on the characteristics of the accumulated protein or the main deposition site. It is important to differentiate amyloidosis from other fibrillary depositions that may cause a similar

Correspondence: Sait ŞEN

Department of Pathology, Ege University, Faculty of Medicine, IZMIR, TURKEY

E-mail: sait.sen@ege.edu.tr Phone: +90 2323904560 
appearance $(2,3)$. Renal involvement is an important cause of morbidity and mortality. Various articles have reviewed the morphological and clinical features of renal amyloidoses and commented on the challenges (4-6).

Amyloidoses seen in cases such as infection, inflammation or Familial Mediterranean Fever (FMF) are called AA amyloidosis. Amyloid A(SAA) is the deposited precursor protein. Renal involvement is common. The most common cause of renal amyloidosis in Mediterranean countries is AAA. Typing of AA amyloidosis by immunohistochemistry (IHC) is reported to be reliable $(7,8)$.

Amyloidosis related to light chain disease (AL), a form of systemic amyloidosis, is observed more often in Western and developed countries. Hereditary amyloidoses make up less common renal forms (Afib, AApoAI, AApoAII, Alys, and ATTR) (5). IHC methods and other laboratory data can cause problems in the differential diagnosis of these forms (9-14). Some hereditary amyloidoses have been incorrectly interpreted as AL in the past $(15,16)$. AL and the hereditary amyloidoses do not react with AA immunohistochemically and can therefore be classified as nonAA amyloidoses.

The frequency of renal amyloidosis in renal needle biopsies (RNB) is higher in our country than others (17-21). AA amyloidosis is also reported frequently in contrast to other countries. A 288-case renal amyloidosis series based on RNBs from our country has reported nonAA amyloidosis incidence as $10 \%(21)$.

Using currently available information, the cases that had been diagnosed as nonAA in our department in the last 11 years were re-evaluated. We tried to define the clinical and etiopathological features and prognosis of nonAA amyloidoses and the challenges related to pathological diagnosis.

\section{MATERIAL and METHOD}

All cases with RNB evaluated at our department between 1997 and 2008 were included in this retrospective study. The reports and archive preparations of the cases with a diagnosis of amyloidosis were re-evaluated. AntiAA amyloid had not been routinely used until 2004 and therefore one preparation stained with hematoxylin\&eosin (H\&E) for all cases with a diagnosis of amyloidosis was decolored and applied Anti AA amyloid IHC. The tissue samples left on the blocks of the cases were stored to be used for more advanced methods and therefore new sections were not prepared.
We obtained the clinical data of the patients from the biopsy forms, patient folders nephrology or hematology departments or the hospital computerized database.

The histopathology of RNB and the main features pointing to the diagnosis of amyloidosis are defined below.

Routine evaluations: All RNB had been sent to our department in phosphate buffer solution, without being fixated. The biopsies were evaluated under dissection microscope and then a cortical tissue sample 1-4 mm in size depending on the biopsy size was frozen for immunoflorescence (IF) microscopy if such an indication was present. The remaining biopsy sample was fixed in $4 \%$ formalin for light microscope evaluation and embedded in paraffin following routine procedures.

Light microscopy investigation was performed on three 2-4 $\mu \mathrm{m} H \& \mathrm{E}$ sections and also one section each stained with Putchler's Congo Red (CR), Masson's trichrome, Schiff's periodic acid (PAS) and Jones' silver stain methods (22).

Sections 4-6 microns thick were prepared on 12 slides from a frozen RNB sample to be stained with the direct fluorescent method. We routinely used antibodies tagged with fluorescence isothiocyanate (FITC) for IgG, IgM, IgA, $\mathrm{C} 3 \mathrm{c}, \mathrm{C} 1 \mathrm{q}$ and fibrin, and in the last two years, kappa and lambda (1:20 dilution, Dako, Glostrup, Denmark).

Diagnosis and scoring of amyloidosis: A diagnosis of amyloidosis was made when CR-stained deposits on paraffin and/or frozen sections showed apple-green birefringence under the polarizing microscope. The main accumulation site of amyloid deposits (glomerular, vascular or interstitial), glomerular accumulation pattern, accumulation type and density and other changes in the renal parenchyme together with amyloid deposits were evaluated on the microscope and the findings were scored (4). The cases were classified as early, middle and late stage amyloidosis according to the total renal amyloid prognostic score (RAPS).

Typing of amyloid deposits: AntiAA IHC evaluation was performed in all cases (M 0759, 1:100 dilution, Dako, CA, USA). Anti lambda and kappa monoclonal antibodies were also used in the paraffin blocks from 2008 (4 cases). Sections were put on electrostatic charged slides (XtraTM, Surgipath Medical Industries, Richmond, IL, USA) and dried at $60^{\circ} \mathrm{C}$ for at least two hours. All the staining process including deparaffinization and antigen exposure procedures was performed on the Ventana, BenchMark XT fully automated IHC staining device. Counter stain was completed in the device with hematoxylin and blueing agent. The IHC staining was completed with dehydration, xylene clarification and lamella closure. IHC staining had been performed by hand for biopsies before 2005 . 
Only those deposits that stained with antiAA IHC were typed as AA amyloidosis among the deposits that stained with $\mathrm{CR}$ and showed polarization. When there was weak staining and multiple antibody staining, typing was performed together with the IF evaluation, and clinical and laboratory data. Cases without AA staining were primarily typed as nonAA systemic amyloidosis and included in the study.

Potassium permanganate CR (PerCR) staining was not used after 2003 as it is not reliable (22).

Non-renal biopsy materials of the cases: Non-renal biopsy materials of nonAA cases were obtained from the pathology department and the reports were evaluated. The preparations (especially bone marrow biopsies) of those cases that had prognostically important features were reevaluated. However, new sections were not obtained from the paraffin blocks and IHC staining was not performed so as not to cause tissue loss as regards future studies.

Follow-up of nonAA cases: The follow-up and treatment of the cases were found from the hospital records. We defined whether renal failure had developed or not, its duration, treatment administered for plasma cell dyscrasia and the final status of the patient. Renal failure was disregarded if the renal failure and death had occurred in the same month. Cases whose records did not disclose the status in the 6 months following the final follow-up and those that could not be reached were followed-up until the last followup and categorized as 'final status unknown'.

\section{RESULTS}

A total of $6468 \mathrm{RNB}$ materials were evaluated at our department during the study period. Of these, 2660 were native and 3808 transplant RNB. Transplant RNB consisted of approximately 1000 transplant cases and included renal implantation biopsies and follow-up biopsies. Native RNB were estimated to include 5\% follow-up and repeat biopsies at the most and the actual patient number was estimated at around 2500 .

A total of 222 biopsies from 210 cases received a diagnosis of amyloidosis in the study period. RNB from 20 transplant cases made up 24 of these (2\%). Only one was de novo AA amyloidosis (primary kidney disease; adult type polycystic kidney disease) and the rest were recurrent AA amyloidosis. Amyloidosis was diagnosed in 198 (approximately 8\%) of the native RNB and $30(1.2 \%)$ of these were evaluated as nonAA. The AA amyloidosis to nonAA amyloidosis ratio was $85 / 15$.
A total of 30 cases (33 RNB) with a diagnosis of nonAA amyloidosis were included in the study. The biopsy was repeated in 3 cases. One biopsy was repeated after 3 years and amyloidosis was found. The interstitial amyloid deposits at the first biopsy had been evaluated as fibrosis (case 1). No amyloid deposits had been found in RNB at another center but the new biopsy and the newly evaluated old biopsy were found to show amyloidosis (case 11). No renal parenchyme was seen in the first biopsy of the third case and an amyloidosis diagnosis could not be made. The second RNB was evaluated together with the muscle biopsy and amyloidosis was diagnosed (case 18).

The average age was $53(\mathrm{SD} \pm 10.76$, youngest 34 , oldest 75$)$ and the male/female ratio $14 / 16$ for the nonAA cases. Table I presents the detailed information and organ involvement for the cases.

The RNB indication was proteinuria in only 4 cases and the nephrotic syndrome in the remaining cases. Of these cases, the clinical picture was complemented with multiple myeloma in 8 , diabetes mellitus in 2 , plasma cell dyscrasia in 2 and acute renal failure in 2 cases. A bone marrow biopsy diagnosis was present in 5 of the multiple myeloma cases and in the cases with dyscrasia. No family history of amyloidosis or FMF was defined in any case.

Table I presents the glomerular amyloid deposit pattern and the prognostic indexes of the cases. Glomerular amyloid deposition was not found in one case and the diagnosis was made with deposits on the vessel wall (case 24). The deposits were more marked in the interstitium in an unusual manner in one case and this will be discussed later (case 1). The deposits had an early amyloidosis pattern in 5 cases (pattern 1) and 3 were defined as early amyloidosis according to the RAPS score. The deposits were generally of the membranous pattern in 9 cases (pattern 5). Advanced glomerulosclerosis was present in 3 cases. There were membranous and mesangial deposits of various degrees in the glomerules in the remaining cases.

Amyloid deposits were accompanied by various degrees of interstitial and vascular deposits and also chronic tubulointerstitial fibrotic and inflammatory changes. RAPS, total of the scores of all findings, revealed that only 4 cases had been diagnosed at the early stage (RAPS stage $=1$ ), and 10 cases had advanced stage late changes (RAPS stage $=$ 3).

Kappa and lambda were investigated by IHC in paraffin blocks in 5 cases diagnosed in 2008 and only one case was found to be lambda positive. The bone marrow biopsy of this case was diagnosed as plasma cell dyscrasia. 
Table II presents the bone marrow diagnoses and amyloid deposits in bone marrow and findings related to the amyloid deposits in other biopsies of performed to explain the myeloma or plasma cell dyscrasias. There were no healthy data regarding amyloid deposits in the biopsy in 8 of the 19 cases with bone marrow biopsies. Amyloid deposits were reported in the other biopsies. Rectum biopsies had been performed in 6 cases and no deposits found in 3 . There were no healthy data regarding amyloid deposits in 6 biopsies obtained from the skin or subcutaneous tissue in
8 cases. Gastric biopsies had been performed in 4 cases and amyloid deposits reported in 2 .

Renal failure developed in 12 cases with known clinical course and dialysis was performed. The mean duration until renal failure was 19 months. However, the duration was over 4 years in 3 cases. This affected the mean value (cases 1,3 and 17). The RNB of case 17 that received a diagnosis of myeloma were requested from the first center after amyloidosis was diagnosed in the other biopsies and it was found that very early amyloidosis deposits had not

Table I: Clinical and pathological features of nonAA amyloidosis cases

\begin{tabular}{|c|c|c|c|c|c|c|}
\hline Case & $S$ & A & Glomerular Pattern & RAPS Stage & Syndrome and comorbidities & Extra-renal involvement \\
\hline 1 & $\mathrm{~F}$ & 44 & 2 & 3 & NS & Lv, Spleen \\
\hline 2 & $\mathrm{M}$ & 52 & 5 & 2 & $\mathrm{NS}+\mathrm{COPD}$ & $\mathrm{Lv}$ \\
\hline 3 & $\mathrm{~F}$ & 52 & 5 & 2 & $\mathrm{NS}+\mathrm{MM}$ & Lv, GIS \\
\hline 4 & $\mathrm{M}$ & 47 & 5 & 2 & NS & Heart, Lv \\
\hline 5 & $\mathrm{M}$ & 59 & 4 & 3 & $\begin{array}{l}\text { Proteinuria-COPD+diabetes } \\
\text { mellitus }\end{array}$ & $\mathrm{Lv}$ \\
\hline 6 & $\mathrm{M}$ & 66 & 1 & 1 & NS & \\
\hline 7 & $\mathrm{M}$ & 62 & 5 & 2 & NS + diabetes mellitus & PNS, heart \\
\hline 8 & $\mathrm{M}$ & 37 & 5 & 2 & NS & Spleen \\
\hline 9 & $\mathrm{~F}$ & 41 & 2 & 2 & $\mathrm{NS}+(\mathrm{AL}-\mathrm{L})$ & Lv, spleen \\
\hline 10 & $\mathrm{~F}$ & 53 & 4 & 2 & NS+ARF & \\
\hline 11 & $\mathrm{M}$ & 34 & 2 & 2 & NS & PNS \\
\hline 12 & $\mathrm{M}$ & 75 & 4 & 3 & $\mathrm{NS}+\mathrm{ARF}$ & \\
\hline 13 & $\mathrm{~F}$ & 40 & 1 & 1 & NS & \\
\hline 14 & $\mathrm{M}$ & 48 & 1 & 2 & $\mathrm{NS}+\mathrm{MM}$ & \\
\hline 15 & $\mathrm{~F}$ & 57 & 1 & 2 & $\mathrm{NS}+\mathrm{MM}$ & \\
\hline 16 & $\mathrm{~F}$ & 67 & 5 & 3 & Proteinuria & Heart \\
\hline 17 & $\mathrm{M}$ & 53 & 1 & 1 & $\mathrm{NS}+\mathrm{MM}$ & Heart, PNS \\
\hline 18 & $\mathrm{M}$ & 39 & 5 & 2 & Proteinuria & Lv, PNS \\
\hline 19 & $\mathrm{~F}$ & 44 & 3 & 2 & $\mathrm{NS}+\mathrm{MM}$ & GIS \\
\hline 20 & $\mathrm{~F}$ & 50 & 2 & 2 & NS + plasma cell dyscrasia & \\
\hline 21 & $\mathrm{~F}$ & 49 & 4 & 2 & NS & GIS \\
\hline 22 & $\mathrm{~F}$ & 64 & 4 & 2 & $\mathrm{NS}+\mathrm{MM}$ & Heart, Lv, spleen, PNS \\
\hline 23 & $\mathrm{~F}$ & 56 & 6 & 3 & NS & Lv, PNS, heart \\
\hline 24 & $\mathrm{M}$ & 69 & 0 & 1 & NS & \\
\hline 25 & $\mathrm{~F}$ & 70 & 4 & 3 & NS & \\
\hline 26 & $\mathrm{M}$ & 59 & 5 & 2 & Proteinuria & Heart \\
\hline 27 & $\mathrm{~F}$ & 44 & 6 & 3 & NS + plasma cell dyscrasia & \\
\hline 28 & $\mathrm{M}$ & 58 & 6 & 3 & $\mathrm{NS}+\mathrm{MM}$ & Heart \\
\hline 29 & $\mathrm{~F}$ & 50 & 5 & 3 & NS & Heart, Lv, PNS, spleen \\
\hline 30 & $\mathrm{~F}$ & 40 & 5 & 3 & $\mathrm{NS}+\mathrm{MM}$ & PNS \\
\hline
\end{tabular}

Abbreviations; S, sex; A, age; F, female; M, male; NS, nephrotic syndrome; MM, multiple myeloma; ARF, acute renal failure; COPD, chronic obstructive pulmonary disease; Lv, liver; PNS, peripheral nervous system; GIS, gastrointestinal system 
Table II: Diagnoses of bone marrow biopsies with amyloid deposits at various sites and clinical courses

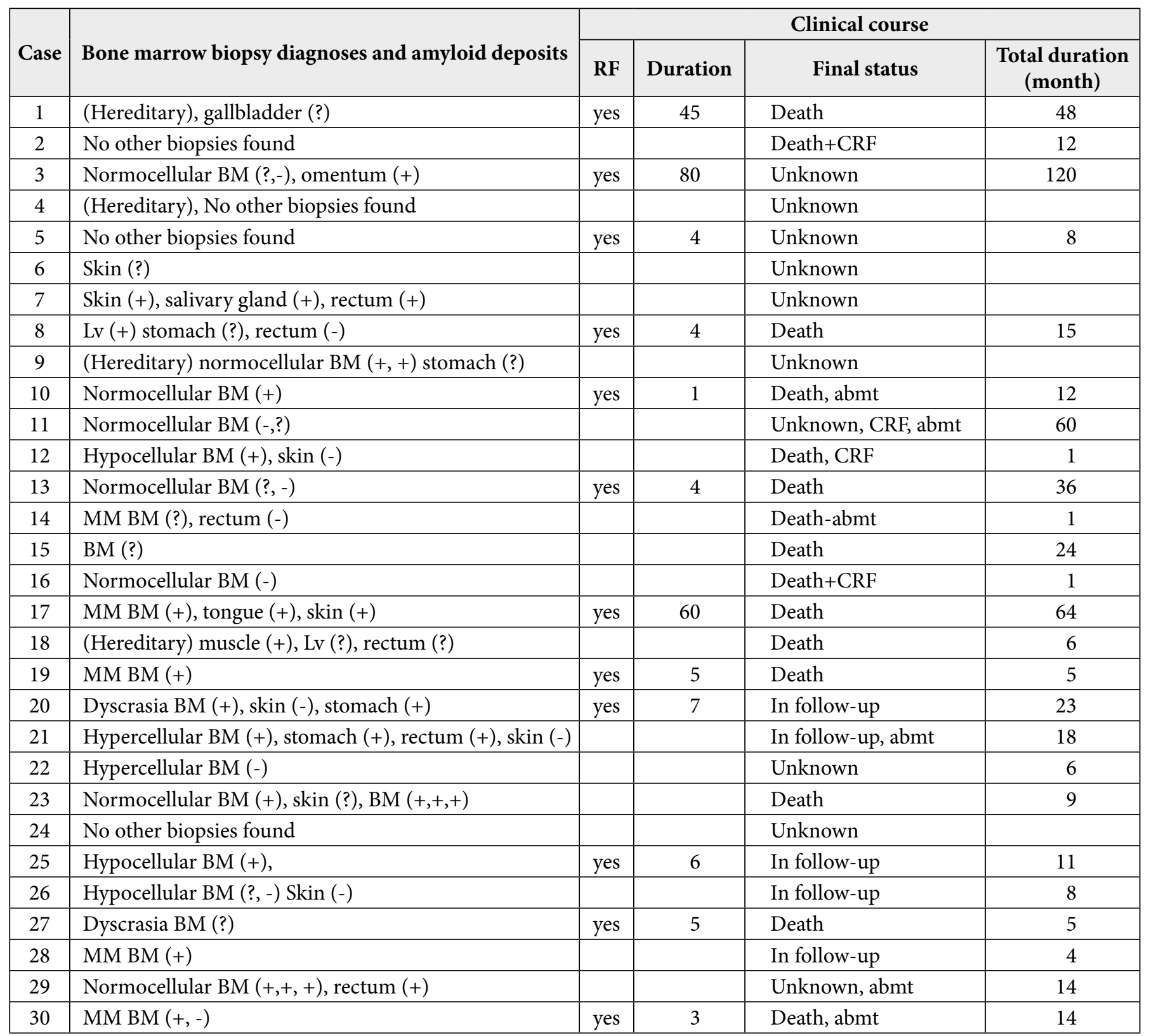

Abbreviations; BM, bone marrow; MM, multiple myeloma; (Hereditary), case very much suspect for hereditary amyloidosis; (?), amyloid deposits in tissue not specified; Lv, liver; CRF, renal failure; abmt, autologus bone marrow transplantation; +, amyloid positive; -, amyloid negative.

been diagnosed. These cases will be discussed in detail.

Fifteen cases with clinical follow-up were found to have died after 17 months on average. These two cases (case 1 and 17) again affected the mean value. Five cases were lost in the first 6 months and a total of 8 in the first year. Five cases are still being followed-up with a mean follow-up period of 12 months. The last status of 10 cases is unknown and 5 of these have been followed-up for an average of 42 months. However, they were lost to follow-up afterwards.
These cases have probably also died. We will discuss two cases (case 3 and 11) with the longest follow-up period.

\section{Cases with interesting features}

Cases with interesting clinical and pathological features are discussed in detail below.

Case 1: A 44-year-old female had been complaining of edema for one year and had undergone RNB for the first time in 1997 where the amyloidosis deposits that had 
caused chronic interstitial tubular atrophy were not defined. A second RNB was performed 3 years later and amyloid deposits were found. Two of the 14 glomerules were sclerotic in the first RNB and the glomerules contained minimal amyloid. Of the 24 glomerules in the second RNB, 90\% were globally sclerotic. Amyloid deposition in the interstitium and the intact glomerules were striking (Figure 1), and focal deposits were found with anti AA amyloid. However, repeated IHC staining of both biopsies and the clinical course led to a diagnosis of non AA and AL amyloidosis. The marked interstitial amyloid deposits indicated hereditary apolipoprotein AI amyloidosis (AApoAI). The patient died shortly after renal failure development.

Case 3: A 52-year-old female underwent RNB in 1997. Amyloid deposits were found in 25 glomerules and she was diagnosed as secondary amyloidosis at that time as permanganate CR evaluation was negative. A monoclonal peak was found on protein electrophoresis on later followup and the case was diagnosed as and treated for multiple myeloma. Renal failure developed approximately 5 years later and dialysis was started. The bone marrow biopsies (BMB) did not reveal any significant finding supportive of myeloma and no amyloid deposits were found in the second $\mathrm{BMB}$. The patient was later investigated for ascites and amyloid deposits were found on peritoneal biopsy. Retrospective antiAA investigation in RNB revealed

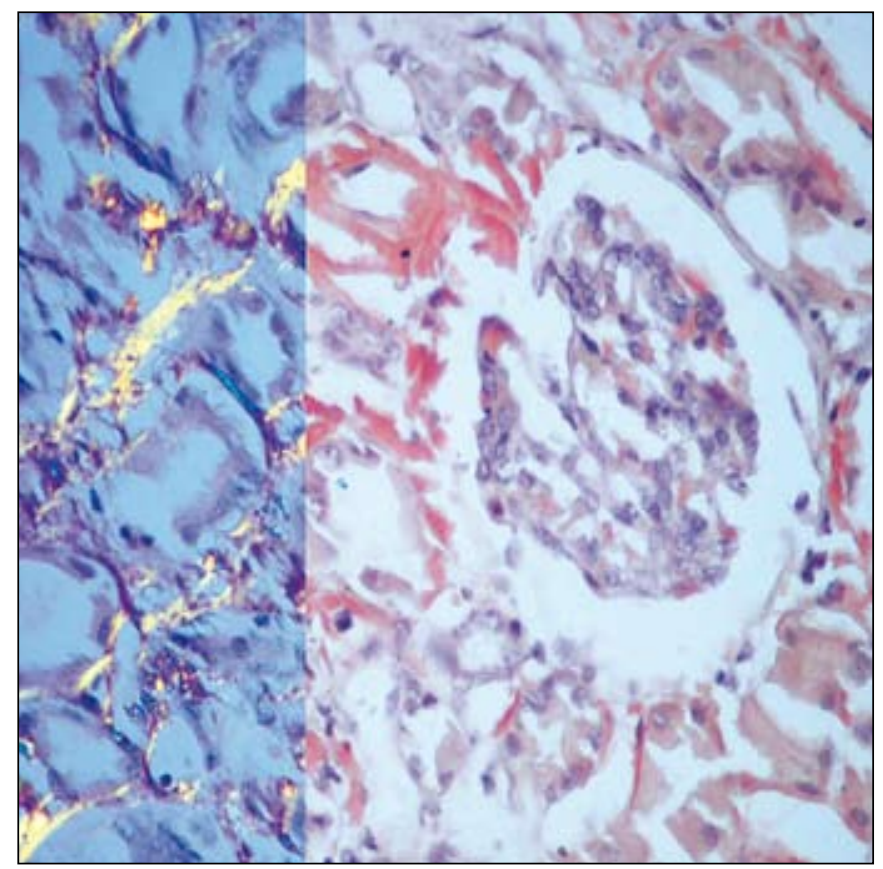

Figure 1: Renal biopsy of nonAA amyloidosis shows interstitial amyloid deposits on the background and apple-green birefringence on the left of the figure (Case 1, Congo red, x200).
nonAA deposits. The deposit in this case was probably due to hereditary amyloidosis.

Case 11: A 34-year-old male underwent RNB at another center with a preliminary diagnosis of nephrotic syndrome and the histopathological features were interpreted as focal segmental glomerulosclerosis with no CR staining. $\mathrm{He}$ underwent a new biopsy at our center approximately 10 months after this biopsy and was diagnosed as amyloidosis. The previous biopsy was also re-evaluated and amyloid deposits were demonstrated. Progression of glomerular and tubulo-interstitial changes were noted in the new biopsy. No positivity was found in the first antiAA IHC investigation. Immunoperoxidase investigation revealed lambda positivity, indicating AL-lambda. The patient also underwent an autologous bone marrow transplantation and was lost to follow-up 5 years later. Bone marrow biopsies did not show plasma cell pathology or amyloidosis. This case also needs to be investigated for hereditary amyloidoses due to his age and other features.

Case 17: A 53-year-old male underwent a biopsy from his skin lesions and from the ulcerous lesion on the his side of the tongue later due to a suspicion of malignancy; however no malignancy was found. Subseguent bone marrow biopsy revealed myeloma, with lambda positivity and amyloidosis. Renal failure developed in the meantime and it was determined that the patient had undergone RNB four years before. We did not perform a new RNB and re-evaluated the previous RNB and biopsies. Amyloidosis deposits were demonstrated in all biopsies. All deposits were found antiAA negative. The case died four months after the diagnosis. The amyloid deposit in the first RNB were interpreted as pattern 1 and RAPS early stage (Figure 2). The case was interpreted as $\mathrm{AL}$ amyloidosis arising with a clinical picture of multiple myeloma developing during follow-up.

Case 18: A 39-year-old male who had been followed up at another center with a preliminary diagnosis of polymyositis had undergone a muscle biopsy and a RNB had followed during the evaluation of the first biopsy due to the clinical findings. No specific findings were present in the muscle biopsy and no renal parenchyme was seen on the RNB. The RNB was repeated with only 4 glomerules being found in the new biopsy and amyloidosis was suspected. The previous muscle biopsy were re-evaluated and a diagnosis of nonAA amyloidosis was made as the deposits found in both biopsies did not stain with antiAA. Subsequent liver and rectum biopsies of the case did not produce any notes regarding amyloidosis. The patient died 8 months after the first diagnosis. The deposits in this case were also suspicious regarding hereditary amyloidoses. 
Cases 4, 9, 13, and 24 have features indicating hereditary amyloidoses. There was no significant clinical feature indicating plasma cell pathology in these cases.

Case 13: A 39-year-old female underwent RNB for nephrotic syndrome and early amyloidosis deposits were found. There are no later biopsies and follow-ups in this case where no positivity was found with anti AA IHC.

Case 24: A 68-year-old male underwent RNB because of nephrotic syndrome and focal segmental glomerulosclerosis. The biopsy showed 16 glomerules and one was globally sclerotic. The interstitium showed focal, mild fibrosis, tubular atrophy and mild thickening of glomerule basal membranes. There was marked intimal fibrosis in the arteries and amyloid deposits on the vessel wall (Figure 3). No glomerular amyloid protein and immunoglobulin or light chain deposits were found in this case. The case was antiAA negative on IHC and there are no other biopsies or follow-ups.

\section{DISCUSSION}

It is important to detect amyloid deposits in RNB to make a diagnosis of systemic amyloidosis $(1,2)$. Progression to end-stage renal disease can be slowed down with specific treatments or the control of the underlying etiological factor, suppression of amyloidosis precursor proteins and early diagnosis (23-26). Survival is known to be relatively higher in AA amyloidosis compared to AL amyloidosis. End-stage renal disease develops with progression of the disease. Renal treatments such as dialysis or transplantation may be required (27-29). However, dialysis-related amyloidosis ( $\beta 2$-microglobulin amyloidosis, $\mathrm{A} \beta 2 \mathrm{M}$ ) may be added to the picture with long-term dialysis. Amyloid deposits may also appear in the transplanted kidney following renal transplantation or de novo deposits may appear as we defined in one case (27-29).

We defined the incidence of amyloidosis in RNB in our study. This data is similar to previous data from our country. Amyloidosis has been found in approximately 7\% of kidney biopsies from the Aegean region with annual averages of 4$12 \%$ according to data from the last 15 years (4). Our rate for native biopsies was approximately $8 \%$ and the mean value for amyloidosis in the last two years was $10 \%$ with an apparent increase. The incidence in other countries is less than $5 \%(1,6,30-35)$.

There are no healthy data regarding the prognostic significance of the amyloid deposit features and density (36-43). The deposits are usually of the arteriolar and glomerular mesangiocapillary type with the interstitial area

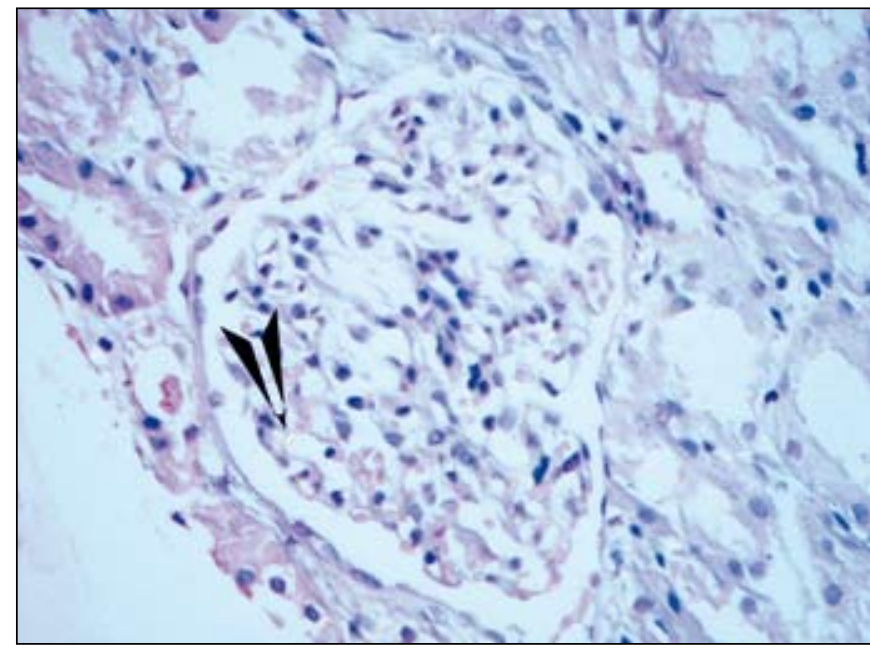

Figure 2: Membranous amyloid deposits that show apple-green birefringence on polarization in early nonAA amyloidosis (AL amyloidosis; multiple myeloma, Lambda-related) are shown with an arrow. The inset shows amyloid deposits in the bone marrow with Congo red and polarization can be seen in the right half (Case 17, Congo red, x200).

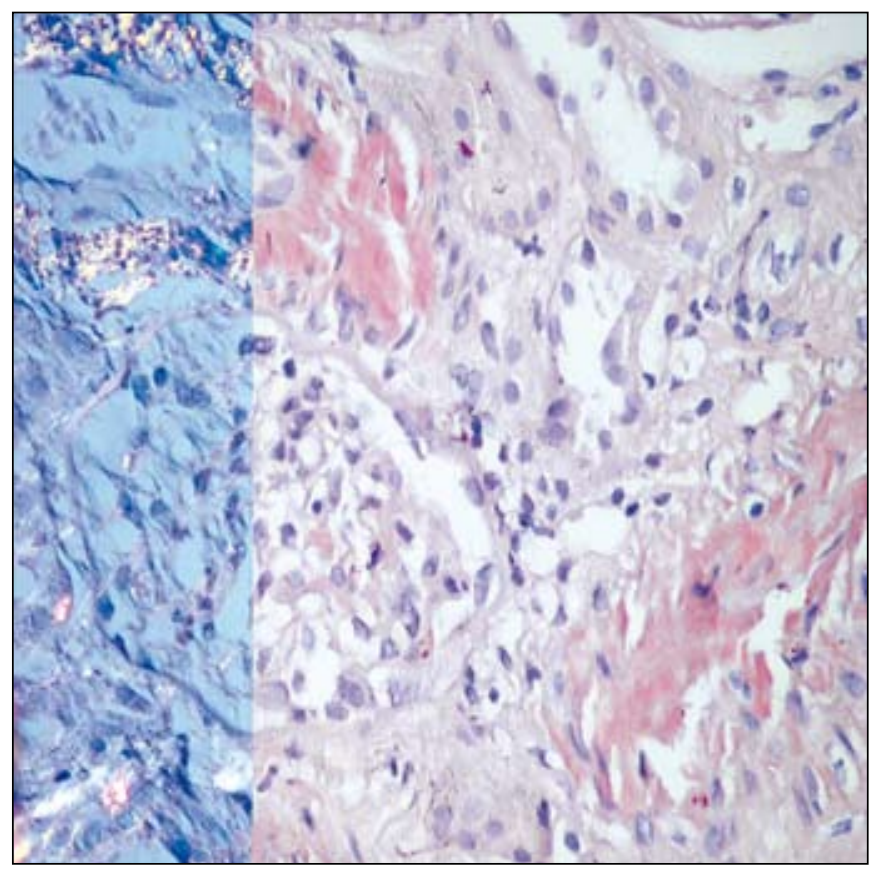

Figure 3: A 68-year-old male with more prominent amyloid deposits on the vessel wall with Congo red. Apple-green birefringence is seen on the left of the figure (Case 24, Congo red, x200).

also involved with increased deposits in the AA type. The deposits are mostly in the glomerular basal membrane in the AL type (6,36-39). These features have been emphasized in a study aiming to standardize the reporting of renal amyloid deposit (4). We also re-evaluated RNB to provide a standardization in our study. Cases with early deposits 
(pattern 1 or 5, RAPS early stage) seemed to have longer follow-ups than other cases. Amyloid deposits on the basal membrane were most striking in RNB but mixed deposits were also noted.

Amyloid protein should be typed for prognosis and treatment in cases with a diagnosis of renal amyloidosis. CR continues to be the gold standard for diagnosis. However, amyloid typing according to whether the CR stain is lost or remains stable following permanganate processing has now been abandoned (12-14). Some cases diagnosed as systemic amyloidosis due to amyloid deposits on RNB may not reveal amyloid deposits on other organ biopsies. This may be due to the organ selectiveness of amyloid protein and also the pathologist's experience, laboratory conditions and the microscopic equipment. During the re-evaluation of the biopsies of some cases in our study, we also found some amyloid deposits that had not been recognized. Reevaluation of previous biopsies for amyloid before RNB is performed has been recommended for cases where amyloidosis is suspected (44). However, RNB may be performed as it shows target organ damage and we think it is easier to diagnose renal amyloid deposits. Although KB has been said to be risky in amyloidosis cases, there are no reliable studies supporting this notion.

From the pathologic point of view, typing may be performed using immunohistochemical methods but the success rate is reported as $38-87 \%(9-12,15,16)$. This range may be due to the population characteristics of the study groups and the physiological characteristics of amyloid proteins. Immunohistochemical typing is more reliable in AA amyloidosis in general but there are problems associated with typing $\mathrm{AL}$ and hereditary amyloidoses.

AA IHC can also be used with the CR fluorescence technique when required $(45,46)$. However, the results of the anti-lambda and anti-kappa commercial antibodies used for AL amyloidosis diagnosis have not been satisfactory. Some investigators suggested their own non-commercial antibodies. These antibodies can produce false negative results while some immunoglobulins and other proteins that become mixed up with amyloid deposits can cause a false positive result. Protein modification or defective immunoglobulins produced by neoplastic cells are blamed for false negativity (9). However, whether the tissue used for typing is frozen or embedded in paraffin can also lead to different results.

Biochemical typing of amyloid proteins is accepted the most reliable method (47). Biochemical typing by extracting protein from formalin-fixated, paraffin-embedded tissue has been tried for years. This method is suggested for definite typing but there are no relevant studies from our country as far as we know.

We only performed antiAA IHC investigation due to the reasons above. We kept our old paraffin block in case they may needed for future biochemical studies regarding protein typing. We performed kappa, lambda staining on paraffin blocks and frozen tissues in the last two years. We also added fibrinogen, transtiretin and $\beta 2$-microglobulin to our amyloid panel as IHC in the last year. However, clinical data and the results of the other organ biopsies are still needed for reliable typing. We also observed staining with more than one antibody besides AA, with lambda being the most common in some cases. Other studies have reported similar findings $(10,18)$. There are no commercial antibodies for Apolipoprotein I, II and gelsolin deposited in other nonAA amyloidoses as far as we know. Many pathology laboratories are not able to perform IHC for all amyloid proteins.

The distribution of amyloidosis types is different than data from developed countries just as in the amyloidosis detection rate. Studies from our country have provided a rate of $90 \%$ for AA amyloidosis but there are no healthy data on AL and hereditary amyloidoses (17-20). The AA/nonAA amyloidosis ratio had increased to $85 / 15$ in our study.

We believe that our nonAA amyloidosis group may include hereditary amyloidoses in addition to AL amyloidoses. The most common hereditary renal amyloidoses are Apolipoprotein AI (AApoAI), Fibrinogen $\alpha$-chain (AFib), Gelsolin (Agel), Lysozyme (ALys) and Transthyretin (ATTR) amyloidosis (48-51).

$\mathrm{AL}$ amyloidosis is the most common type in the USA and is derived from light chains, usually lambda. There may be plasma cell dyscrasias, multiple myeloma, B-cell lymphoproliferative disease and macroglobulinemia as the underlying disease. It is more common in Caucasians. The rate in males is double the rate in females. The mean age at diagnosis is $65.99 \%$ of the patients are aged 40 or over. Histological demonstration of amyloidosis and detection of monoclonal gammopathy are not enough to diagnose AL amyloidosis. Approximately $10 \%$ of cases diagnosed as AL amyloidosis are in fact heredofamilial amyloidosis $(15,16)$.

Bone marrow biopsy is important to determine plasma cells and clonality. AL amyloidosis develops in $6-15 \%$ of multiple myeloma and 3\% of benign monoclonal gammopathy. A bone marrow biopsy was performed in $60 \%$ of the cases in this study. A diagnosis of myeloma was made in only 4 and plasma cell dyscrasia in 2. Amyloid deposits were 
confirmed in most biopsies. However, the mean age is around 50 even in cases with a diagnosis of myeloma and this is not much different than the mean age of the whole nonAA amyloidosis group.

Some cases reported in detail had features of nonAL amyloidosis in addition to the nonAA type. These cases demonstrated findings significant for hereditary amyloidoses. Many neuropathic and cardiopathic hereditary amyloidoses can cause deposits in the kidney even if clinically silent and these are found in RNB at increasing rates. Renal failure related to a mutation may be seen in some ATTR amyloidoses. Glomerular involvement is only expected in Afib amyloidosis and renal failure develops rapidly. Dominant extraglomerular deposits have been defined in AApoAI amyloidosis and renal failure findings are more prominent than those of proteinuria. The clinical development and progress of hereditary amyloidoses vary from case to case. One of our cases (case 1) had a finding that was especially significant for AApoAI amyloidosis. Cases $3,4,9,11$, and 18 were also suspected for hereditary amyloidoses regarding age and clinical features. Case 24 was suspicious for ATTR as there was only vessel involvement. A wide immunohistochemical panel investigation and clinicopathological correlation are required in these cases. AL amyloidosis was not clinically suspected in some cases.

This study covered a wide range of time over a 10 -year period and the changing knowledge regarding amyloidosis made it possible for us to observe the different clinical approaches. Various hematological treatments including autologous bone marrow transplantation were performed in some cases of AL or undefined amyloidosis while there was no amyloidosis-related intervention in some cases. Cases with follow-up generally died within one year after the diagnosis. Cases with long-term follow-up were generally suspected for hereditary amyloidosis but it was not possible to make a definite diagnosis as more advanced diagnostic methods were not used. The prognosis is known to be unfavorable in AL amyloidoses. Kidney, and sometimes kidney plus liver transplantation may be required in hereditary amyloidoses. Typing the deposited amyloid protein is therefore important.

Better documentation of hereditary amyloidosis cases and setting a case database in the future, together with more widespread use of genetic and protein analysis in our country will make it possible to better define these cases.

One must also remember that there are important hereditary diseases that cause AA amyloidosis and that FMF is especially significant for our country. Other hereditary AA diseases are the tumor necrosis factor receptor-associated periodic syndrome (TRAPS), the Muckle-Wells syndrome and periodic fever with IgD hyperimmunoglobulinemia.

The increasing treatment options for renal amyloidosis necessitate early diagnosis and correct typing of amyloidosis. We presented cases of nonAA amyloidosis using the accumulated knowledge of recent years and defined challenges regarding immunohistochemical typing in this study. A definite diagnosis requires detailed clinical information, other laboratory data, genetic evaluation and amyloid protein type analysis from formalin-fixated, paraffin-embedded tissues in these cases. Specialized multidisciplinary centers are therefore required for the diagnosis and treatment of nonAA cases.

\section{ACKNOWLEDGEMENTS}

We would like to thank Dilek Pelvan and Hayriye Köktaş for helping us during the immunohistochemical investigations; Hasibe Kömür for the Congo Red staining; Gökşen Ertutar for immunofluorescent staining and Dr. Tamer Şahin and Dr. Funda Taşlı for making it possible for us to evaluate the other biopsies of the cases, and the faculty members of our department.

\section{REFERENCES}

1. Westermark P, Benson MD, Buxbaum JN, Cohen AS, Frangione B, Ikeda S, Masters CL, Merlini G, Saraiva MJ, Sipe JD: A primer of amyloid nomenclature. Amyloid 2007, 14:179-183

2. Herrera GA, Picken MM: Renal diseases associated with plasma cell dyscrasias, amyloidoses, Waldenström macroglobulinemia and cryoglobulinemic nephropathies. In: Jennette JC, Olson JL, Schwartz MM, Silva FG, eds. Heptinstalls Pathology of the Kidney. 6th ed., Philadelphia, Lippincott Williams \& Wilkins, 2006, 853-910

3. Striker LJMM, Preud'homme JL, D'Amico G, Striker GE: Monoclonal gammopathies, mixed cryoglobulinemias and lymphomas. In: Tisher CC, Brenner BM, eds. Renal Pathology, with Clinical and Functional Correlations. 2nd ed., Philadelphia, JB Lippincott Co, 1993, 1442-1490

4. Sen S, Sarsik B: A proposed histopathological classification, scoring and grading system for renal amyloidosis; standardization of renal amyloid biopsy report. Archives of Pathology and Laboratory Medicine. 2009, In print

5. Dember LM: Amyloidosis-associated kidney disease. J Am Soc Nephrol 2006, 17:3458-3471

6. Nishi S, Alchi B, Imai N, Gejyo F: New advances in renal amyloidosis. Clin Exp Nephrol 2008, 12:93-101

7. Linke RP, Gärtner HV, Michels $H$ : High-sensitivity diagnosis of AA amyloidosis using Congo red and immunohistochemistry detects missed amyloid deposits. J Histochem Cytochem 1995, 43:863-869

8. Röcken C, Shakespeare A: Pathology, diagnosis and pathogenesis of AA amyloidosis. Virchows Arch 2002, 440:111-122 
9. Picken MM, Herrera GA: The burden of "sticky" amyloid: typing challenges. Arch Pathol Lab Med 2007, 131:850-851

10. Linke RP, Oos R, Wiegel NM, Nathrath WB: Classification of amyloidosis: misdiagnosing by way of incomplete immunohistochemistry and how to prevent it. Acta Histochem 2006, 108:197-208

11. Kebbel A, Röcken C: Immunohistochemical classification of amyloid in surgical pathology revisited. Am J Surg Pathol 2006, 30:673-683

12. Picken MM: New insights into systemic amyloidosis: the importance of diagnosis of specific type. Curr Opin Nephrol Hypertens 2007, 16:196-203

13. Hazenberg BP, van Gameren II, Bijzet J, Jager PL, van Rijswijk MH: Diagnostic and therapeutic approach of systemic amyloidosis. Neth J Med 2004, 62:121-128

14. Satoskar AA, Burdge K, Cowden DJ, Nadasdy GM, Hebert LA, Nadasdy T: Typing of amyloidosis in renal biopsies: diagnostic pitfalls. Arch Pathol Lab Med 2007, 131:917-922

15. Novak L, Cook WJ, Herrera GA, Sanders PW: AL-amyloidosis is underdiagnosed in renal biopsies. Nephrol Dial Transplant 2004, 19:3050-3053

16. Lachmann HJ, Booth DR, Booth SE, Bybee A, Gilbertson JA, Gillmore JD, Pepys MB, Hawkins PN: Misdiagnosis of hereditary amyloidosis as AL (primary) amyloidosis. N Engl J Med 2002, 346:1786-1791

17. Tuglular S, Yalcinkaya F, Paydas S, Oner A, Utas C, Bozfakioglu S, Ataman R, Akpolat T, Ok E, Sen S, Düsünsel R, Evrenkaya R, Akoglu E: A retrospective analysis for aetiology and clinical findings of 287 secondary amyloidosis cases in Turkey. Nephrol Dial Transplant 2002, 17:2003-2005

18. Ensari C, Ensari A, Tümer N, Ertug E: Clinicopathological and epidemiological analysis of amyloidosis in Turkish patients. Nephrol Dial Transplant 2005, 20:1721-1725

19. Paydas S: Report on 59 patients with renal amyloidosis. Int Urol Nephrol 1999, 31:619-631

20. Cakalagaoglu F, Ikinci A, Koc M, Arıkan H: Renal amyloidosiscorrelation morphology and clinical features. Virchows Archiv 2007, 451:515 (poster presentation).

21. Şen S, Sarsık B, Yazıcı A: Classification and scoring system of renal amyloidosis; experience with 288 cases. Virchows Archiv 2007, 451:516-517 (poster presentation).

22. Wowles GH, Francis RJ: Amyloid. Eds. Bancroft JD and Gamble M. In Theory and Practice of Histological Techniques, 5th ed., Edinburg, Churchill Livingstone, 2001, 303-324

23. Sanchorawala V, Wright DG, Seldin DC, Falk RH, Finn KT, Dember LM, Berk JL, Quillen K, Anderson JJ, Comenzo RL, Skinner M: High-dose intravenous melphalan and autologous stem cell transplantation as initial therapy or following two cycles of oral chemotherapy for the treatment of AL amyloidosis: results of a prospective randomized trial. Bone Marrow Transplant 2004, 33:381-388

24. Comenzo RL, Vosburgh E, Falk RH, Sanchorawala V, Reisinger J, Dubrey S, Dember LM, Berk JL, Akpek G, LaValley M, O'hara C, Arkin CF, Wright DG, Skinner M: Dose-intensive melphalan with blood stem-cell support for the treatment of AL (amyloid light-chain) amyloidosis: survival and responses in 25 patients. Blood 1998, 91:3662-3670

25. Dember LM, Hawkins PN, Hazenberg BP, Gorevic PD, Merlini G, Butrimiene I, Livneh A, Lesnyak O, Puéchal X, Lachmann
HJ, Obici L, Balshaw R, Garceau D, Hauck W, Skinner M: Eprodisate for AA Amyloidosis Trial Group. Eprodisate for the treatment of renal disease in AA amyloidosis. N Engl J Med 2007, 356:2349-2360

26. Ben-Chetrit E, Levy M: Colchicine: 1998 update. Semin Arthritis Rheum 1998, 28:48-59

27. Duman S, Şen S, Töz H, Aş̧̧ı G, Başdemir G, Baş̧̧ı A: AA amyloidosis in renal transplantation. Proceedings Bantao 5th Congress of the Balkan Cities Association of Nephrology Dialysis Transplantation and Artificial Organs. Thessaloniki 2001, 252254

28. Sherif AM, Refaie AF, Sobh MA, Mohamed NA, Sheashaa HA, Ghoneim MA: Long-term outcome of live donor kidney transplantation for renal amyloidosis. Am J Kidney Dis 2003, 42:370-375

29. Ozdemir BH, Ozdemir FN, Sezer S, Sar A, Haberal M: Among therapy modalities of end-stage renal disease, renal transplantation improves survival in patients with amyloidosis. Transplant Proc. 2006, 38:432-434

30. Schena FP: Survey of the Italian Registry of Renal Biopsies. Frequency of the renal diseases for 7 consecutive years. The Italian Group of Renal Immunopathology. Nephrol Dial Transplant 1997, 12:418-426

31. Bergesio F, Ciciani AM, Santostefano $M$, Brugnano $R$, Manganaro M, Palladini G, Di Palma AM, Gallo M, Tosi PL, Salvadori M: Immunopathology Group, Italian Society of Nephrology. Renal involvement in systemic amyloidosis--an Italian retrospective study on epidemiological and clinical data at diagnosis. Nephrol Dial Transplant 2007, 22:1608-1618

32. Bergesio F, Ciciani AM, Manganaro M, Palladini G, Santostefano M, Brugnano R, Di Palma AM, Gallo M, Rosati A, Tosi PL, Salvadori M: Immunopathology Group of the Italian Society of Nephrology. Renal involvement in systemic amyloidosis: an Italian collaborative study on survival and renal outcome. Nephrol Dial Transplant 2008, 23:941-951

33. Rivera F, López-Gómez JM, Pérez-García R: Spanish Registry of Glomerulonephritis. Clinicopathologic correlations of renal pathology in Spain. Kidney Int 2004, 66:898-904

34. Davison AM: The United Kingdom Medical Research Council's glomerulonephritis registry. Contrib Nephrol 1985, 48:24-35

35. Haas M, Meehan SM, Karrison TG, Spargo BH: Changing etiologies of unexplained adult nephrotic syndrome: a comparison of renal biopsy findings from 1976-1979 and 1995-1997. Am J Kidney Dis 1997, 30:621-631

36. Watanabe T, Saniter T: Morphological and clinical features of renal amyloidosis. Virchows Arch 1975, 366:125-135

37. Dikman SH, Churg J, Kahn T: Morphologic and clinical correlates in renal amyloidosis. Hum Pathol 1981, 12:160-169

38. Shiiki H, Shimokama T, Yoshikawa Y, Toyoshima H, Kitamoto T, Watanabe T: Renal amyloidosis. Correlations between morphology, chemical types of amyloid protein and clinical features. Virchows Arch 1988, 412:197-204

39. Shiiki H, Shimokama T, Yoshikawa Y, Onoyama K, Morimatsu M, Watanabe T: Perimembranous-type renal amyloidosis: a peculiar form of AL amyloidosis. Nephron 1989, 53:27-32

40. Nagata M, Shimokama T, Harada A, Koyama A, Watanabe T: Glomerular crescents in renal amyloidosis: an epiphenomenon or distinct pathology? Pathol Int 2001, 51:179-186 
41. Sasatomi Y, Kiyoshi Y, Uesugi N, Hisano S, Takebayashi S: Prognosis of renal amyloidosis: a clinicopathological study using cluster analysis. Nephron 2001, 87:42-49

42. Verine J, Mourad N, Desseaux K, Vanhille P, Noël LH, Beaufils H, Grateau G, Janin A, Droz D: Clinical and histological characteristics of renal AA amyloidosis: a retrospective study of 68 cases with a special interest to amyloid-associated inflammatory response. Hum Pathol 2007, 38:1798-1809

43. Uda H, Yokota A, Kobayashi K, Miyake T, Fushimi H, Maeda A, Saiki O: Two distinct clinical courses of renal involvement in rheumatoid patients with AA amyloidosis. J Rheumatol 2006, 33:1482-1487

44. Şen S, Alkanat MB, Akalın T, Özsan N: Amiloidozis tanısında zorluklar: Böbrek iğne biopsisinden kaçınılabilir mi? Ege Tip Dergisi 2002, 41: 201-206

45. Linke RP: Highly sensitive diagnosis of amyloid and various amyloid syndromes using Congo red fluorescence. Virchows Arch 2000, 436:439-448
46. Sen S, Başdemir G: Diagnosis of renal amyloidosis using Congo red fluorescence. Pathol Int 2003, 53:534-538

47. Murphy CL, Wang S, Williams T, Weiss DT, Solomon A: Characterization of systemic amyloid deposits by mass spectrometry. Methods Enzymol 2006, 412:48-62

48. Hawkins PN: Hereditary systemic amyloidoses with renal involvement. J Nephrol 2003, 16:443-448

49. Benson MD: Ostertag revisited: the inherited systemic amyloidoses without neuropathy. Amyloid 2005, 12:75-87

50. Korbet SM, Bonsib S: A case of polyneuropathy and proteinuria. Clin J Am Soc Nephrol 2008, 3:624-636

51. Gregorini G, Izzi C, Obici L, Tardanico R, Röcken C, Viola BF, Capistrano M, Donadei S, Biasi L, Scalvini T, Merlini G, Scolari F. Renal apolipoprotein A-I amyloidosis: a rare and usually ignored cause of hereditary tubulointerstitial nephritis. J Am Soc Nephrol 2005,16:3680-3686 